Goldschmidt 2021 Abstract

https://doi.org/10.7185/gold2021.7391

\section{Monazite and zircon petrochronological constraints on mechanisms for shallow crustal differentiation: Trois Seigneurs Massif, French Pyrenees}

CHARLOTTE CONNOP AND ANDREW J SMYE

Pennsylvania State University

Presenting Author: cvc5644@psu.edu

Melting of continental crust is required for its chemical differentiation and yet is energetically intensive, requiring significant exogenic or endogenic heat. The prevailing paradigm is that granulite facies metamorphism, partial melting and attendant differentiation occur in the lower structural levels of thickened, radiogenic crust (e.g. [1]). Terranes that preserve evidence for partial melting under shallow crustal conditions thus pose a challenge to this paradigm and demand alternative heat sources and transport mechanisms. In this study, we present results from a monazite $\mathrm{U}-\mathrm{Th}-\mathrm{Pb}$ and zircon $\mathrm{U}-\mathrm{Pb}$ petrochronological investigation of a classic low-pressure hightemperature (LP-HT) metamorphic terrane: the Variscan-age Trois Seigneurs Massif, France [2]. Pseudosections for four Cambro-Ordovician metapelitic samples spanning andalusite+cordierite to migmatite grades constrain the metamorphic field gradient and peak PT conditions. Low-grade andalusite-albite schists with prominent sedimentary layering yield peak conditions of $<4 \mathrm{kbar}$ and $400-580{ }^{\circ} \mathrm{C}$. Higher-grade garnet-cordierite schists record conditions of 3.8-4.4 kbar and $590-690{ }^{\circ} \mathrm{C}$. A migmatitic gneiss records the onset of muscovite dehydration melting at 3.25-6 kbar and $>695{ }^{\circ} \mathrm{C}$. Application of garnet-biotite $\mathrm{Fe}-\mathrm{Mg}$ exchange thermometry, GASP thermobarometry and average P-T reveals a clockwise metamorphic path with minor pressure loss during cooling $(<0.3$ kbar decrease per $100{ }^{\circ} \mathrm{C}$ cooling). Monazite U-Th- $\mathrm{Pb}$ dates from four samples (see Fig 1. For a compilation of yttrium maps for representative grains) in the duration of LP-HT metamorphism to between $317.4 \pm 12.1 \mathrm{Ma}$ and $276.2 \pm 8.7 \mathrm{Ma}$. Monazite U-Th-Pb dates are contemporaneous with zircon $\mathrm{U}-\mathrm{Pb}$ dates derived from a biotite granite unit, contiguous with migmatitic gneisses, constraining the age of crustal anatexis to $306 \pm 3.25 \mathrm{Ma}$. Principal component analysis of monazite REEs identifies a strong influence of garnet growth with decreasing age, as seen in an increasing $\mathrm{Gd} / \mathrm{Yb}$ with decreasing age (see Fig. 2). Combined, these P-T-t data will be used to inform a thermal model for the development of the Trois Seigneurs, constructed to discriminate between different exogenic heat sources such as elevated mantle heat flow and advective emplacement of plutons.

[1] Clark, C., Fitzsimons, I. C. W., Healy, D., \& Harley, S. L. (2011), Elements, 7(4), 235-240. [2] Wickham, S. M. (1987), Journal of Petrology, 28(1), 127-169.
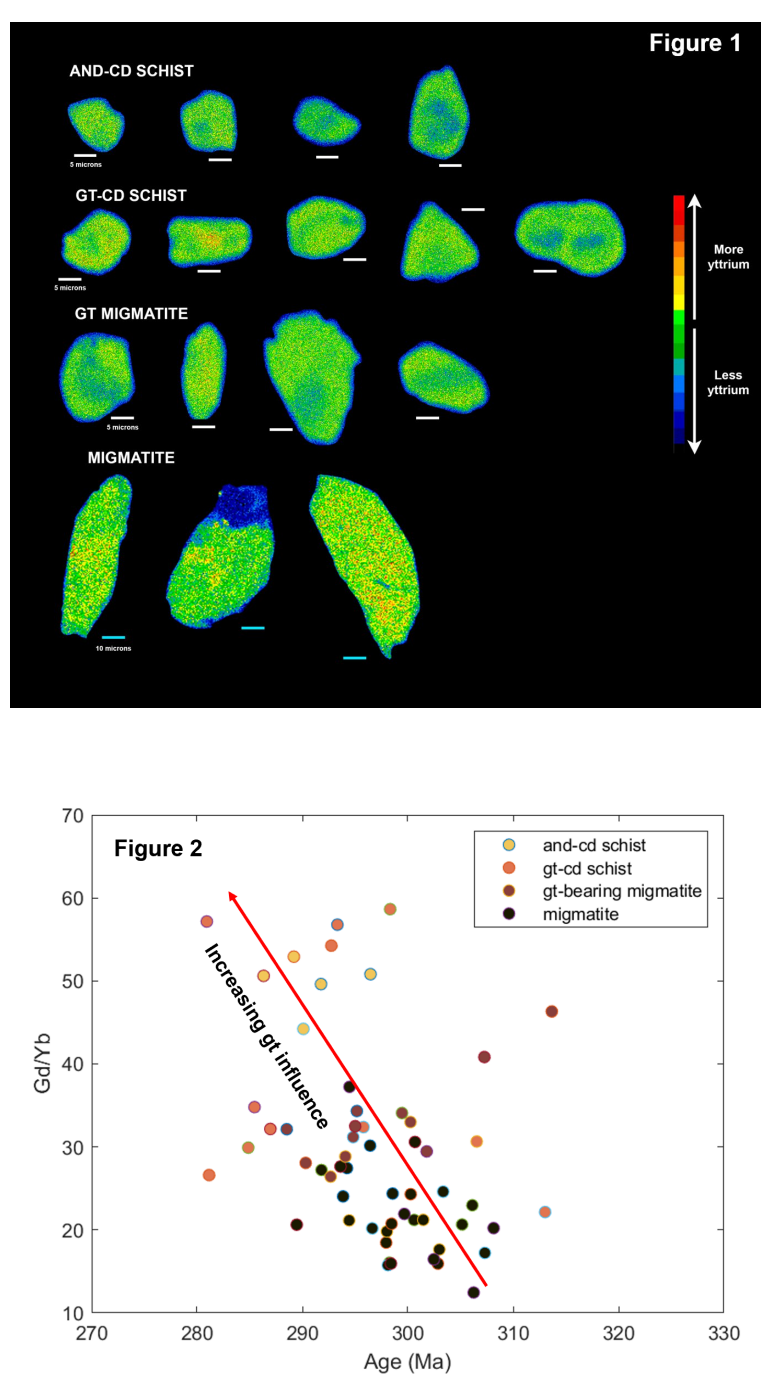